\title{
Roles of TNF- $\alpha$ and lgE in the late phase of contact hypersensitivity induced by trimellitic anhydride
}

\author{
Ok Hee Chai ${ }^{1,4}$, Hern-Ku Lee, \\ Yong Chul Lee ${ }^{3,4}$, Moo Sam Lee ${ }^{1}$, \\ Eui-Hyeog Han ${ }^{1}$, Hyoung Tae Kim ${ }^{1}$ \\ and Chang Ho Song ${ }^{1,4,5}$
}

\author{
${ }^{1}$ Department of Anatomy \\ ${ }^{2}$ Department of Immunology \\ ${ }^{3}$ Department of Internal Medicine \\ Chonbuk National University Medical School \\ ${ }^{4}$ Research Center for Allergic Immune Diseases \\ Chonbuk National University \\ Jeonju, Jeonbuk 561-756, Korea \\ ${ }^{5}$ Corresponding author: Tel, 82-63-270-3101; \\ Fax, 82-63-274-9880; E-mail, asch@chonbuk.ac.kr
}

Accepted 16 August 2005

Abbreviations: A/O, acetone: olive oil solution; $\mathrm{CHS}$, contact hypersensitivity; ESR, ear swelling responses; PMNLs, polymorphonuclear leukocytes; TMA, trimellitic anhydride

\begin{abstract}
Trimellitic anhydride (TMA) is widely used indu strially to make epoxy and alkyd resins, plasticizers and surfactants. The purpose of this study was to investigate whether contact hypersensitivity (CHS) is induced by repeated TMA challenge and the role of TNF- $\alpha$ and IgE in the TMA-induced CHS. The repetition of the challenge enlarged the extent of an early and a late phase of CHS in TNF- $\alpha^{+/+}$(B6129SF2/ $\mathrm{J})$ and Balb/c mice. In the late phase of TMA-induced CHS, the peak of ear swelling responses by single challenge showed at $24 \mathrm{~h}$ after challenge, but the peak was observed at $8 \mathrm{~h}$ after repeated challenge. In the TNF- $\alpha$ knockout TNF- $\alpha^{-1-}$ (B6;129S-Tnf $\left.{ }^{\mathrm{fm} 1 \mathrm{Gk} 1}\right)$ mice, the repetition of the TMA challenges enlarged the extent of the late phase of CHS, but less than those in TNF- $\alpha^{+/+}$mice. Injection of anti-TNF- $\alpha$ antibody into the peritoneal cavity of Balb/c mice significantly decreased the extent of the late phase of CHS. Subcutaneous injection of anti-IgE antibody into Balb/c mice also decreased the extent of the late phase of CHS in dose-dependent manner. Histologically, infiltration of polymorphonuclear leukocytes and eosinophils was more pronounced in repeatedly TMA-challenged TNF- $\alpha^{+/+}$and Balb/c mice than in the
\end{abstract}

TNF- $\alpha^{-1-}$ mice and anti-TNF- $\alpha$ or anti-lgE antibodies treated Balb/c mice. These results indicate that mice sensitized by TMA could possibly offer a useful model to study the mechanism of CHS, and TNF- $\alpha$ and IgE may act as potential modulators in the late phase of TMA-induced CHS. Neutralization of TNF- $\alpha$ and IgE by anti-TNF- $\alpha$ or anti-IgE antibodies may provide therapeutic tools for the treatment of TMA-induced CHS.

Keywords: allergic contact, dermatitis; eosinophils; immunoglobulin E; neutrophils; trimellitic anhydride; tumor necrosis factor

\section{Introduction}

The contact hypersensitivity (CHS) response in mice is a model of clinical allergic contact dermatitis and also widely employed to investigate mechanisms of $T$ lymphocyte-mediated inflammation (Grabbe and Schwarz, 1998; Kim et al., 2003). Studies have demonstrated that local release of cytokines, including TNF- $\alpha, \mathrm{IL}-1$, and IFN- $\gamma$, is critical for the generation of the CHS reaction (Piguet et al., 1991; Kondo et al., 1995; Wang et al., 2003).

TNF- $\alpha$ is a pleiotropic cytokine involved in host defense mechanisms and inflammatory responses (Vassalli, 1992; Shah et al., 1995). TNF- $\alpha$ is produced in responses to various stimuli in a variety of cell types, such as mast cells, macrophages, monocytes, neutrophils, keratinocytes, and T cells (Hofsli et al., 1988; Gordon and Galli, 1990; Ohkawara et al., 1992; Bradding et al., 1994). Neutralizing antibody against TNF- $\alpha$ inhibits the migration of epidermal Langerhans cells in response to hapten sensitization (Cumberbatch and Kimber, 1995). However, direct effect of TNF- $\alpha$ on the TMA-induced CHS in murine model is not fully understood.

Trimellitic anhydride (TMA), a sensitizer that induces occupational asthma, is widely used industrially to make epoxy and alkyd resins, plasticizers, high temperature polymer, and surfactants (Mapp et al., 1999; Zhang et al., 2002). Specific antibodies to TMA have been found in exposed workers, and TMA-induced occupational asthma is thought to be mediated by an IgE-mediated allergic mechanism. TMA also elicits eosinophil infiltration into lungs of sensitized mice (Zhang et al., 2002). IgE antibodies mediate allergic diseases by binding to specific high 
affinity receptors (FcERI) on mast cells and basophils. Increased production of $\lg E$ in response to common environmental antigens is the hallmark of allergic diseases such as bronchial asthma, allergic rhinitis, and atopic dermatitis (Burr, 1993). Some studies showed the roles of $\mathrm{lgE}$ in the development of allergic inflammation, airway hyprresponsiveness, and contact hypersensitivity in a murine model (Haile et al., 1999; Tumas et al., 2001; Yokozeki et al., 2003; Coyle et al., 2005). However, the detailed role of $\lg E$ remains to be characterized.

Therefore, this study has investigated to roles of TNF- $\alpha$ and $\lg E$ in the TMA-induced CHS using TNF- $\alpha^{+}$ mice and a neutralizing anti-TNF- $\alpha$ or $\lg E$ antibodies.

\section{Materials and Methods}

\section{Animals}

Balb/c male mice aged 6 weeks were purchased from Korean Damool Science (Daejeon, Chungnam, Korea). TNF- $\alpha$ knockout (B6; 129S-Tnf ${ }^{\text {m1 }}$-1, TNF$\alpha^{+}$) and original wild type (B6129SF2/J, TNF- $\alpha^{+/+}$) mice were purchased from the Jackson Laboratory (Bar Harbor, ME). Each experimental group consisted of 5 mice. All experiments were repeated at least 2 times with similar results. They were housed in a laminar flow cabinet and artificial lighting conditions with 12-h day/night cycle and had access to food and water ad libitum.

\section{Chemicals}

TMA was purchased from Sigma (MA). A mixture of acetone (Junsei):olive oil (Filippo berio, Italy) (4:1, $\mathrm{v} / \mathrm{v})$ was used as vehicle.

\section{Induction of contact hypersensitivity}

Mice were sensitized on shaved back skin with 50 mg TMA in a 4:1 acetone colive oil solution (A/O) on

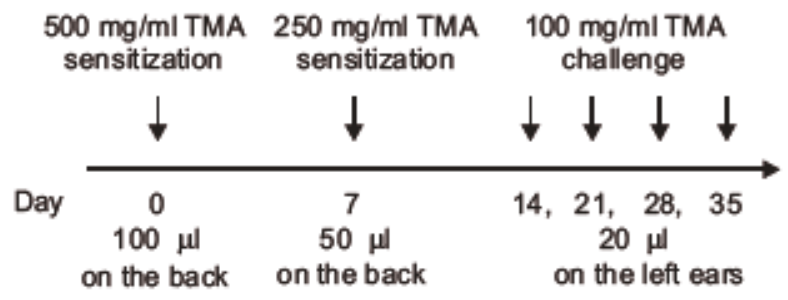

Figure 1. Schematic diagram of the experimental protocol. Mice were sensifized on shaved back skin with $100 \mu \mathrm{l}$ of $500 \mathrm{mg} / \mathrm{ml}$ TMA on day 0 and $50 \mu \mathrm{l}$ of $250 \mathrm{mg} / \mathrm{ml}$ TMA in AOO on day 7 . On days 14, 21, 28, and 35 , left ears were challenged with $20 \mu \mathrm{l}$ of $100 \mathrm{mg} / \mathrm{ml}$ TMA and right ears were applied with $20 \mu \mathrm{l}$ of A/O. day 0 and $12.5 \mathrm{mg}$ TMA on day 7 under light anesthesia according to method described by Lauerma et al., (1997). On days 14, 21, 28 and/or 35, left ears were repeatedly challenged with $2 \mathrm{mg}$ TMA and right ears were repeatedly challenged with $20 \mu \mathrm{l}$ of A/O only (Figure 1).

\section{Treatment of anti-TNF- $\alpha$ or anti-lgE antibodies}

An anti-TNF- $\alpha$ antibody (BD Biosciences, CA; 0.2, 2 or $5 \mathrm{mg} /$ mouse) and control saline were injected into the peritoneal cavity $5 \mathrm{~min}$ before $100 \mathrm{mg} / \mathrm{ml}$ TMA challenge on day 21 (Choi et al., 2003). An anti-lgE antibody (BD Biosciences, CA; $0.2,2$ or $20 \mathrm{mg} /$ mouse) and control saline were injected $24 \mathrm{~h}$ before $100 \mathrm{mg} / \mathrm{ml}$ TMA challenge on day 14 (Haile et al., 1999).

\section{Measurement of ear swelling responses (ESR)}

The ear thickness just before and after the last challenge was measured three times with a dial thickness gauge (Model 7326, Tokyo, Japan). In the time-course study, the ear thickness was measured $1,2,4,8,12,24,48$, and $72 \mathrm{~h}$ after challenge. Ear thickness was expressed in units of $10^{4}$ inches (mean \pm SEM). Ear swelling responses (ESR) were calculated as the following formula.

ESR = [ear thickness after TMA challenge - ear thickness before TMA challenge]

\section{Histological examination}

Seventy-two hours after the last challenge, animals were sacrificed and both ears of animals were excised. Specimens were fixed in $10 \%$ neutral buffered formalin, embedded in paraffin, cut in $4 \mu \mathrm{m}$ section by microtome (SM 2000R, Leica, Germany; Lee et al., 2004). The sections were stained with Wright Giemsa solution for polymorpholeukocytes (Stern et al., 1997) and Congo red solution for eosinophils (Song et al., 1999).

\section{Statistical analysis}

Data were presented as mean \pm standard error of mean (SEM). Student's unpaired $t$-test was applied to determine significant differences between corresponding treated groups and control groups. A value of $P<$ 0.05 was considered statistically significant.

\section{Results}

\section{Trimellitic anhydride induces the biphasic} increase in ESR

Time course of the ESR to the TMA challenges are shown in Figure 2. First challenge of TMA resulted in 
A $\quad$ TNF $-\alpha^{+/+}$mice
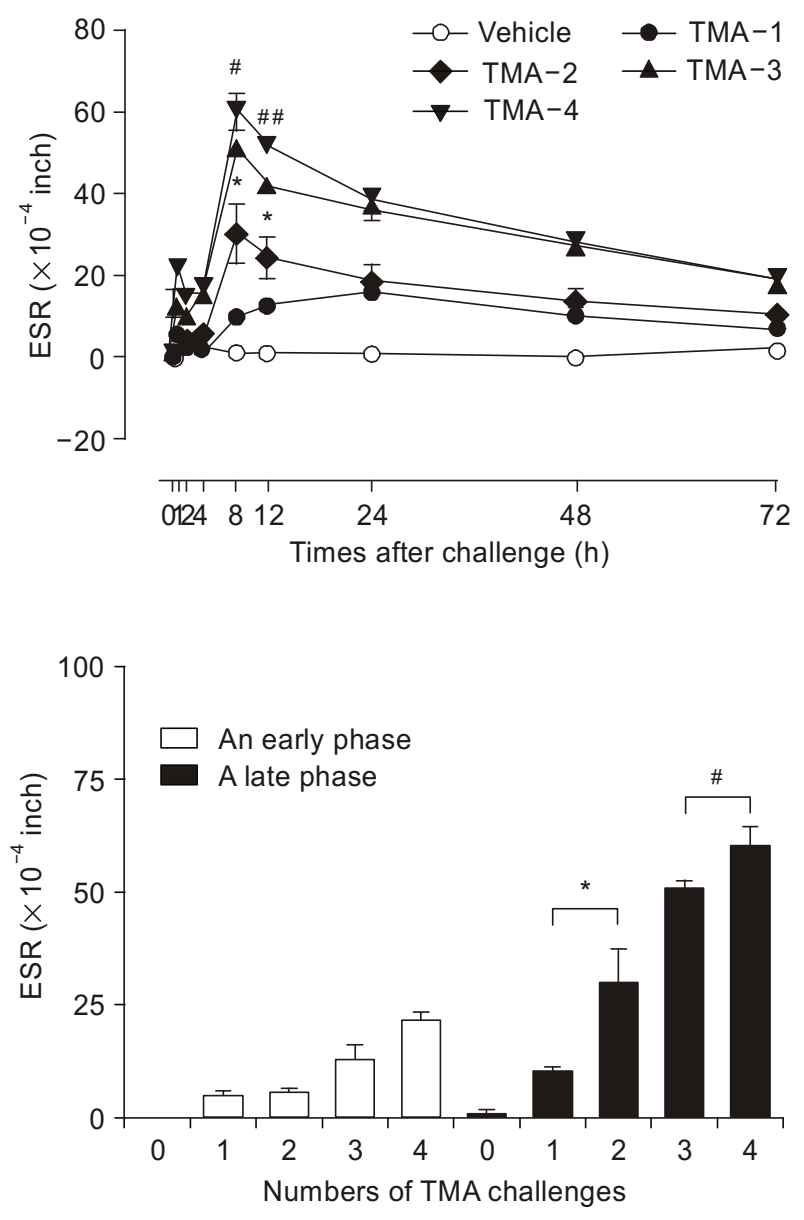

B Balb/c mice
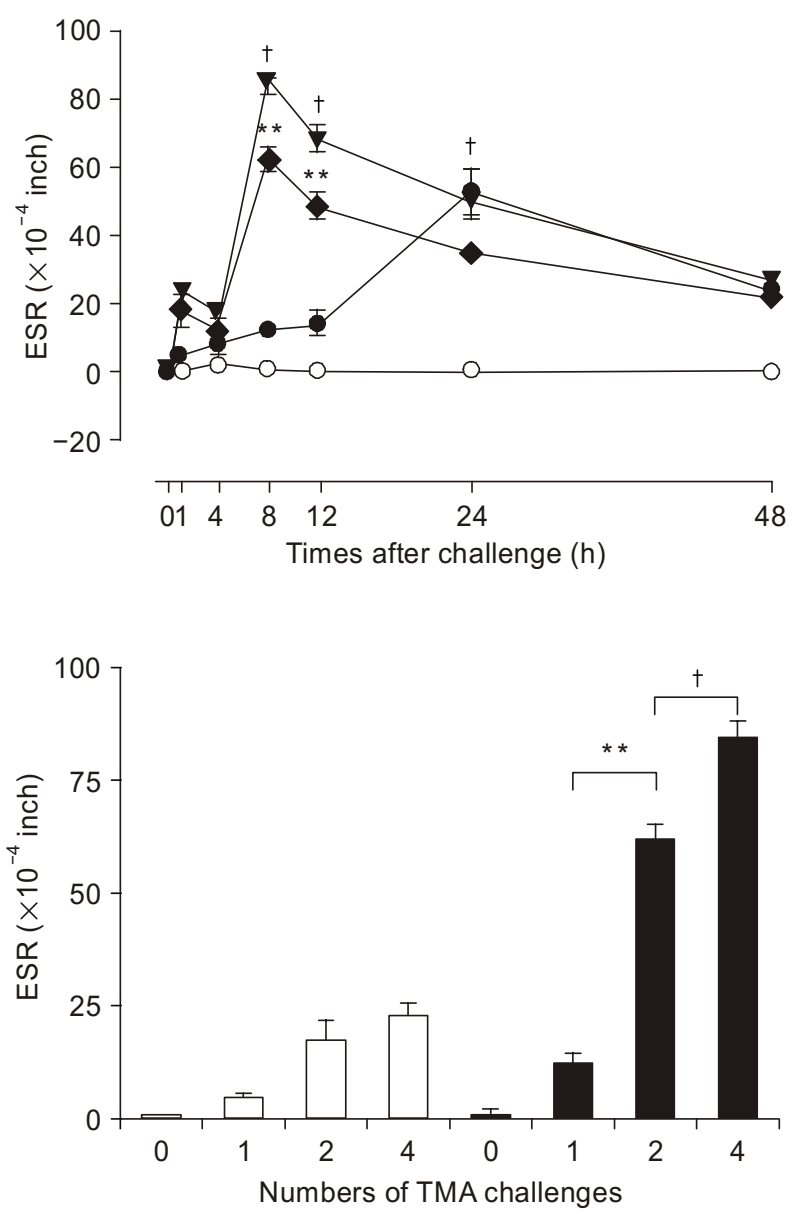

Figure 2. ESR on time course following TMA challenges on the ears of the TNF- $\alpha^{+/+}(B 6129 S F 2 / J)(A)$ and Balb/c (B) mice sensitized on the back skin with TMA. Differences from TMA-1, ${ }^{*} P<0.01 ;{ }^{* *} P<0.001$, from TMA-2, ${ }^{\dagger} P<0.01$ and from TMA-3, ${ }^{\sharp} P<0.01,{ }^{\#} P<0.001$

an increase of the ESR of both Balb/c and TNF- $\alpha^{+/+}$ mice at $1 \mathrm{~h}$ and $24 \mathrm{~h}$ after the challenge, showing a biphasic response. However, the late phase of ESR was significantly greater than the early phase. The late phase response in Balb/c was approximately 1.5 -fold greater than in TNF- $\alpha^{+/+}$mice, suggesting that there are species differences in TMA-induced CHS. Vehicle challenge showed no effects on the ESR. Increase in the number of TMA challenges resulted in the increase of ESR in a challenge number-dependent manner, suggesting that this may not be only cumulative effect of TMA. The late phase of $\mathrm{CHS}$ was observed in both mice groups at $8 \mathrm{~h}$ after TMA challenges. These results indicate that mice sensitized to TMA could possibly offer a useful model to study the mechanism of $\mathrm{CHS}$.

\section{Depletion of TNF- $\alpha$ attenuates the late phase of ESR}

To evaluate whether TNF- $\alpha$ plays a role in developing $\mathrm{CHS}$, we examined the TMA-induced ESR using TNF $-\alpha^{+/+}$and TNF- $\alpha^{-/-}$mice. Time courses of ESR to TMA challenge are shown in Figure 3. First challenge of TMA increased the ESR of both TNF$\alpha^{+/+}$and TNF- $\alpha^{-/-}$mice at $1 \mathrm{~h}$ and $24 \mathrm{~h}$ after the challenge, showing a biphasic response. Vehicle challenge showed no effects on the ESR of both TNF- $\alpha^{+/+}$ and TNF- $\alpha^{-/-}$mice. Increase in the number of TMA challenges resulted in the increase of ESR in a challenge number-dependent manner. The late phase of CHS was observed in both mice groups at $8 \mathrm{~h}$ after TMA challenges. The magnitude of these responses observed according to the frequency of the TMA challenge in TNF- $\alpha^{+/+}$mice was significantly higher than that in TNF- $\alpha^{-\alpha_{-}}$mice. In the group of $4^{\text {th }}$ 

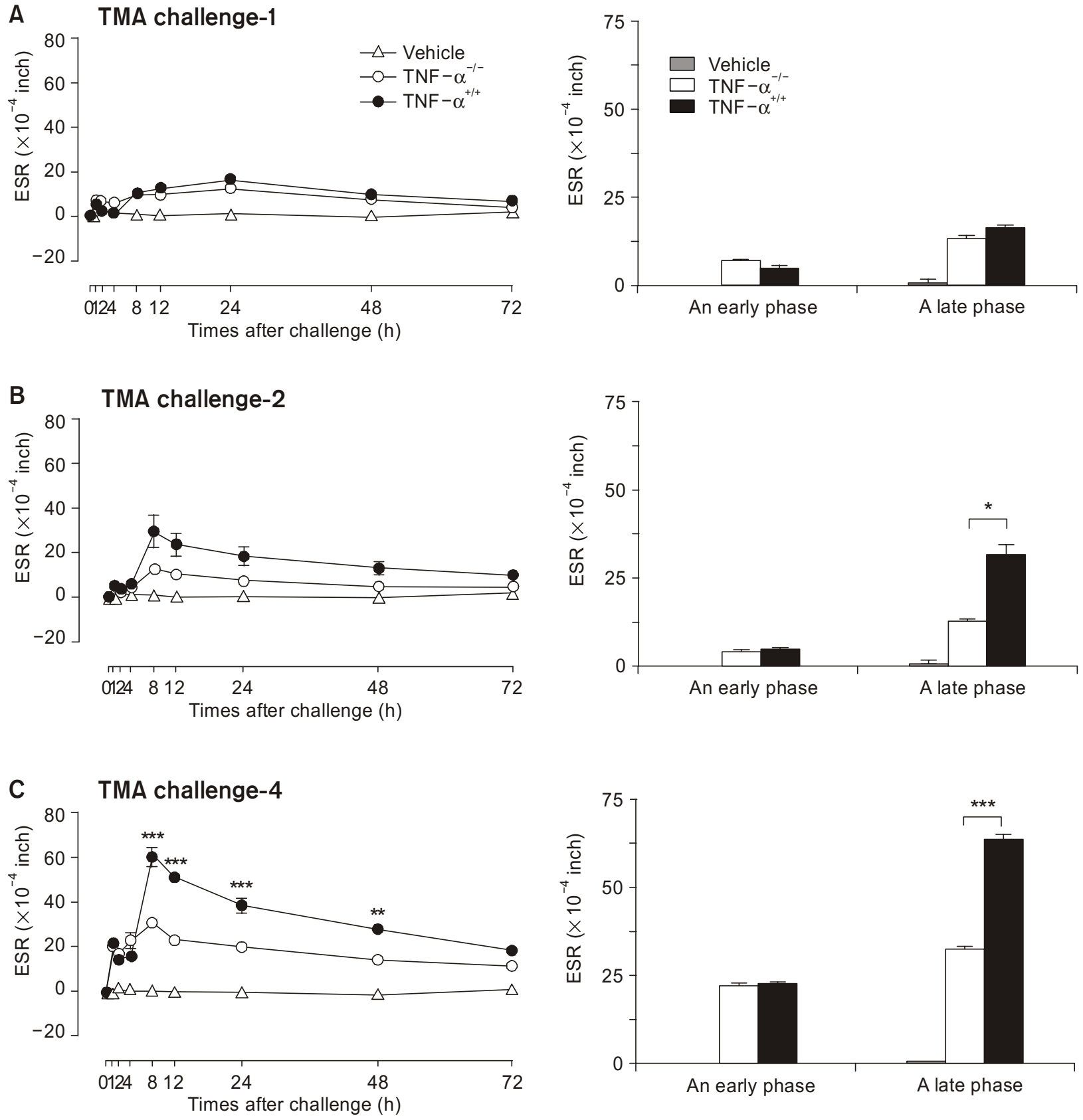

Figure 3. ESR on time course following once (A), twice (B) and four times (C) of TMA challenge on the ears of the TNF- $\alpha$ knockout TNF- $\alpha{ }^{-1 /}$ $\left(\mathrm{B} 6 ; 129 \mathrm{~S}-\mathrm{Tnf}^{\mathrm{fm} 1 \mathrm{Gk} 1}\right.$, open circle) and TNF- $\alpha^{+/+}$(B6129SF2/J, closed circle) mice sensitized on the back skin with TMA. Differences from TNF- $\alpha^{-l_{-}},{ }^{*} P<$ $0.05,{ }^{* *} P<0.01,{ }^{* * *} P<0.001$.

challenge, the late phase of $\mathrm{CHS}$ in TNF- $\alpha^{-1-}$ mice showed approximately 2.5-fold decrease compared to that in TNF- $\alpha^{+/+}$mice. These data indicate that TNF- $\alpha$ is a key cytokine involved in the development of the late phase of CHS.

Inhibition of TNF- $\alpha$ attenuates the late phase of ESR To identify the role of TNF- $\alpha$ in developing $\mathrm{CHS}$, we examined the TMA-induced ESR using Balb/c injected anti-TNF- $\alpha$ antibody into the peritoneal cavity at $5 \mathrm{~min}$ before the second TMA challenge. Pretreatment of anti-TNF- $\alpha$ antibody inhibited the TMAinduced late phase of ESR in a dose-dependent manner, but anti-TNF- $\alpha$ antibody did not attenuate the early phase of ESR (Figure 4). Pretreatment of saline did not inhibit the ESR. The late phase of 

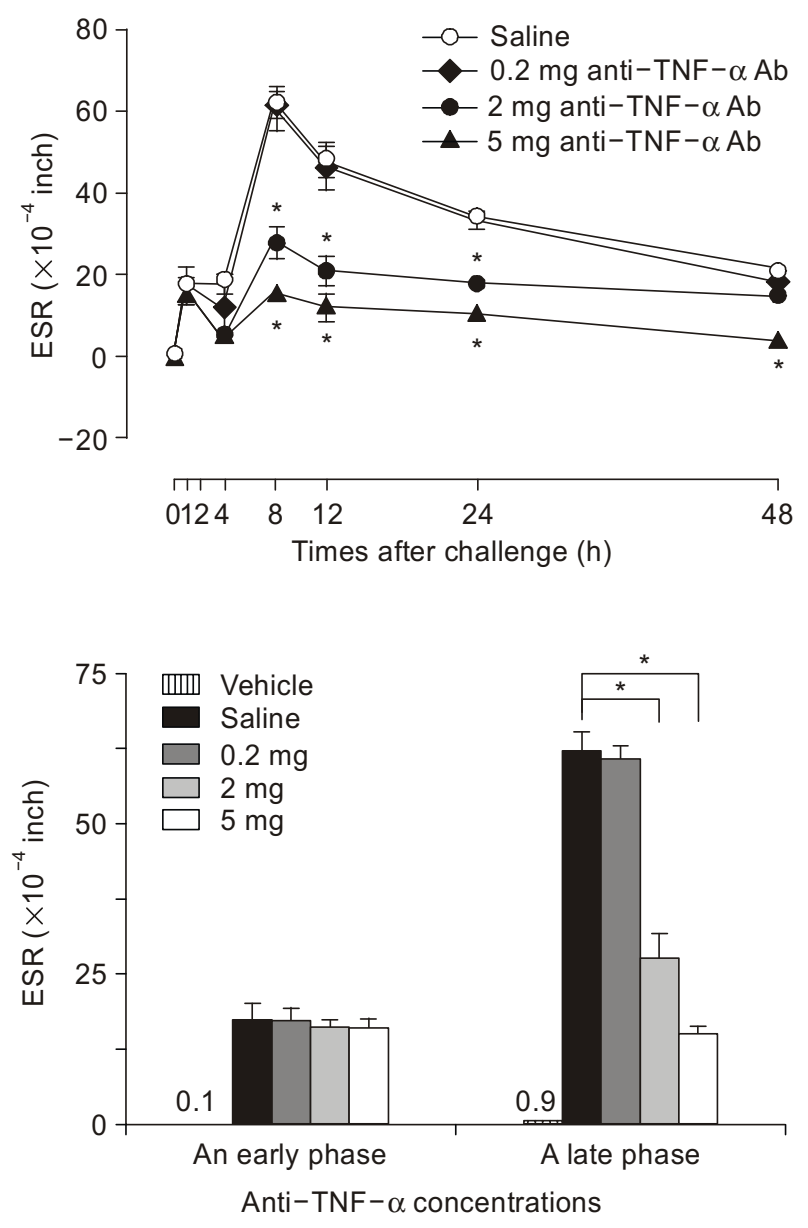

Figure 4. Effect of anti-TNF- $\alpha$ antibody on the TMA-induced ear swelling responses (ESR) in the Balb/c mice. The sensitized mice were challenged with $100 \mathrm{mg} / \mathrm{ml}$ TMA to the left ears on day 14 . On day 21, saline or anti-TNF- $\alpha$ antibody was injected into the peritoneal cavity at $5 \mathrm{~min}$ before the second TMA challenge. Differences from saline, ${ }^{*} P<0.001$.

ESR in anti-TNF- $\alpha$ antibody-injected group was approximately 3.5 -fold lower than in saline-injected control group. These results strongly suggest that the increase of late phase of CHS by repeated TMA challenge may depend on the TNF- $\alpha$ at the site of inflammation.

\section{Inhibition of $\lg E$ attenuates the late phase of ESR}

To evaluate whether IgE plays a role in developing CHS, we examined the TMA-induced ESR using Balb/c subcutaneously injected anti-lgE antibody at $24 \mathrm{~h}$ before the first TMA challenge. Pretreatment of anti-lgE antibody inhibited the TMA-induced late phase of ESR in a dose-dependent manner, and at a concentration of $20 \mu \mathrm{g} / \mathrm{mouse}$, anti-lgE antibody al-
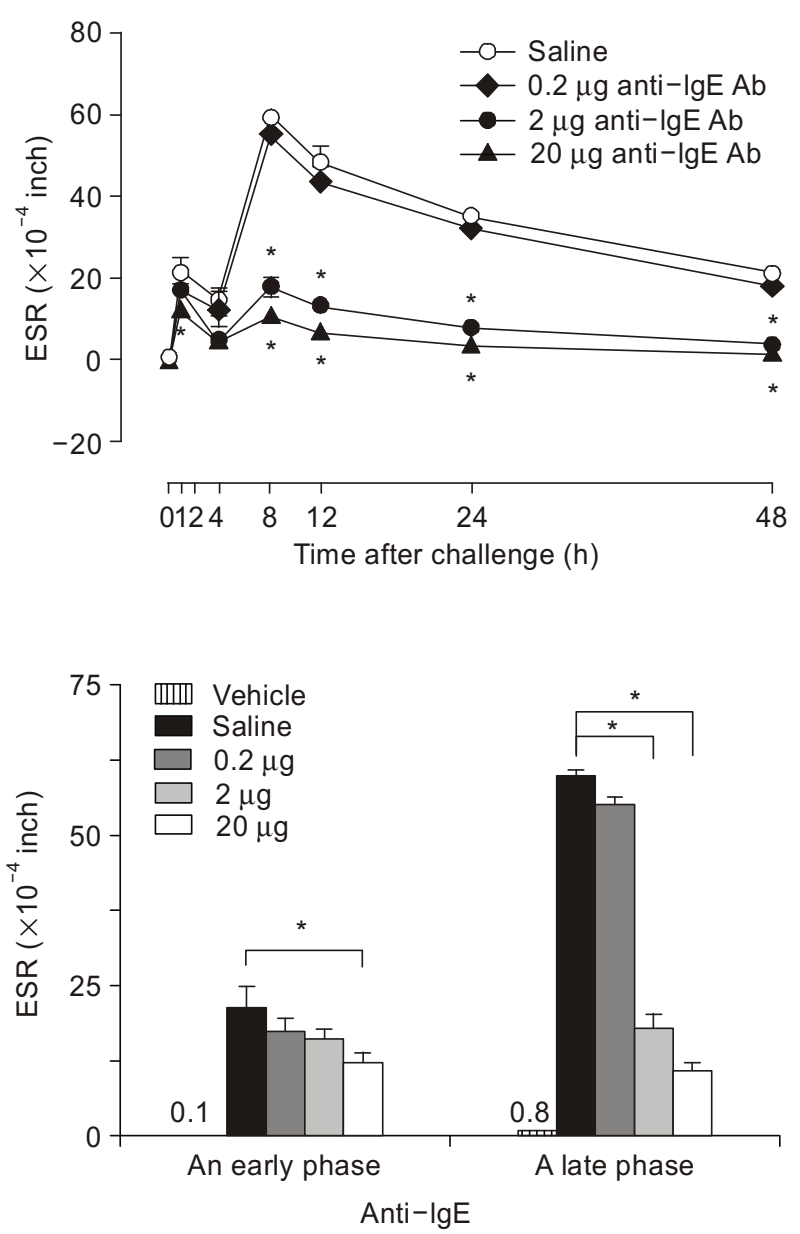

Figure 5. Effect of anti-lgE antibody on the TMA-induced ear swelling responses (ESR) in the Balb/c mice. The sensitized mice were challenged with $100 \mathrm{mg} / \mathrm{ml}$ TMA to the left ears on day 14 . On day 14 , saline or anti-lgE antibody was injected subcutaneously at $24 \mathrm{~h}$ before the first TMA challenge. Differences from saline, ${ }^{*} P<0.001$.

most completely attenuated the early phase of ESR (Figure 5). Pretreatment of saline did not inhibit the ESR. The late phase response in anti-IgE antibodyinjected group was approximately 4-fold lower than in saline-injected control group. These results strongly suggest that $\lg E$ is associated with the late phase responses of repeated TMA challenge.

Inhibition of TNF- $\alpha$ or IgE attenuates trimellitic anhydride-induced leukocyte infiltration into the dermis of the ears

The infiltration of polymorphonuclear leukocytes (PMNLs) and eosinophils were determined as a cellular mechanism underlying ESR. As shown Figures 6 and 7, TMA challenge resulted in an induction of the significant infiltrations of PMNLs and 

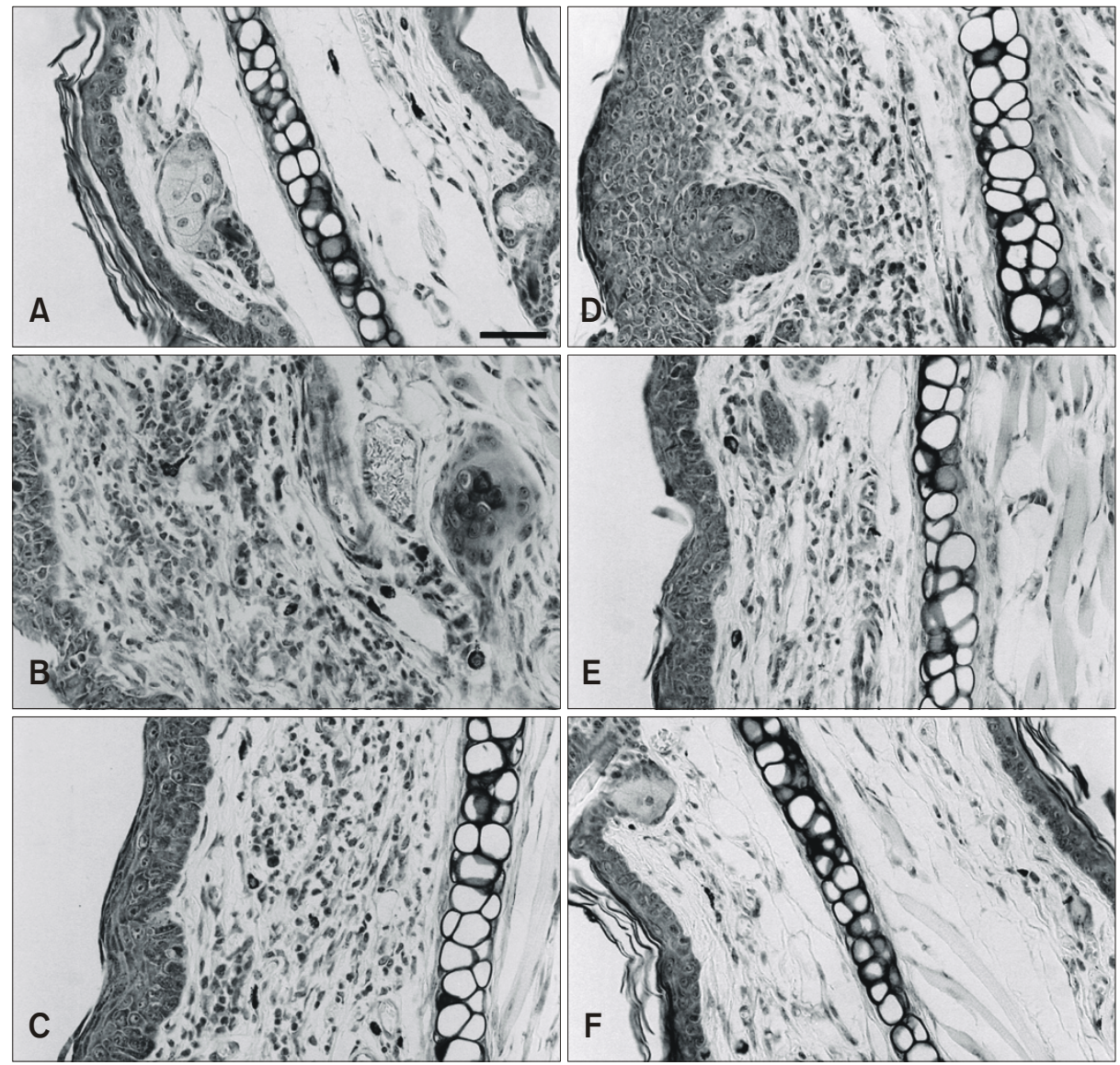

Figure 6. Light micrographs of the infiltration of polymorphonuclear leukocytes by repeated TMA challenges from the control (vehicle treated, A), TNF- $\alpha^{+/+}$(B6129SF2/J, B) and TNF- $\alpha$ knockout TNF- $\alpha^{--}$ $\left(\mathrm{B} 6 ; 129 \mathrm{~S}-\mathrm{Tnf}^{\mathrm{fm} 1 \mathrm{Gk} 1}\right.$, C) mice sensitized on the back skin with TMA. The sensitized Balb/c mice were challenged with $100 \mathrm{mg} / \mathrm{ml}$ TMA to the left ears on day 14. On day 21, saline (D) or anti-TNF- $\alpha$ antibody ( 5 $\mathrm{mg} /$ mouse, E) was injected into the peritoneal cavity at 5 min before the second TMA challenge. On day 14 , anti-lgE antibody (20 $\mu \mathrm{g} /$ mouse, $\mathrm{F}$ ) was injected subcutaneously at 24 $h$ before the first TMA challenge. Wright Giemsa stain, Bar $=50 \mu \mathrm{m}$. eosinophils into the dermis of the ears in TNF- $\alpha^{+/+}$ and TNF- $\alpha^{-t-}$ mice. However, the extent of infiltrations of PMNLs and eosinophils observed in TNF- $\alpha^{-/-}$mice was significantly lower than that in TNF- $\alpha^{+/+}$mice. The number of PMNLs and eosinophils per unit area in the ears of TNF- $\alpha^{+/+}$and TNF- $\alpha^{-/-}$mice were shown in Table 1.

To assess the role of TNF- $\alpha$ in developing $\mathrm{CHS}$, we examined the TMA-induced leukocyte infiltration using Balb/c injected with anti-TNF- $\alpha$ antibody into the peritoneal cavity at $5 \mathrm{~min}$ before the second TMA challenge. As shown Figures 6 and 7, TMA challenge induced the infiltrations of PMNLs and eosinophils into the dermis of the ears in saline-treated control mice. However, treatment of anti-TNF- $\alpha$ antibody significantly inhibited the infiltrations of PMNLs and eosinophils.

To examine the role of $\lg E$ in the late phase of CHS, we determined the TMA-induced leukocyte infiltration using Balb/c subcutaneously injected anti$\lg \mathrm{E}$ antibody at $24 \mathrm{~h}$ before the first TMA challenge. As shown Figures 5 and 6, TMA challenge induced the infiltrations of PMNLs and eosinophils into the dermis of the ears in saline-treated control mice. Treatment of anti-IgE antibody significantly inhibited
Table 1. The number of polymorphonuclear leukocytes (PMNLs) and eosinophils (Eos) per unit area $\left(\mathrm{mm}^{2}\right)$ on $72 \mathrm{~h}$ after four repeated TMA challenges in the ears of TNF- $\alpha^{+/+}$and TNF- $\alpha^{-{ }^{-}}$ mice.

\begin{tabular}{cll}
\hline Groups & No. of PMNLs & No. of Eos \\
\hline TNF- $\alpha^{\text {b) }}$ & $584.3 \pm 109$ & $249.0 \pm 81.3$ \\
TNF $^{+-\alpha^{--}}$ & $320.8 \pm 99.7^{*}$ & $113.5 \pm 39.8^{*}$
\end{tabular}

a) The $4 \mu \mathrm{m}$-thickness paraffin sections were stained with Wright Giemsa solution. *Difference from TNF- $\alpha^{+/+}, P<0.05$. ${ }^{\text {b}}$ The 4 $\mu \mathrm{m}$-thickness paraffin sections were stained with Congo red solution. *Difference from TNF- $\alpha^{+++}, P<0.05$.

the infiltrations of PMNLs and eosinophils in a dosedependent manner. Table 2 shows that the number of PMNLs and eosinophils per unit area in the ears of saline-, anti-TNF- $\alpha$ antibody- or anti-lgE antibodyinjected mice. These data indicate that TNF- $\alpha$ or $\operatorname{lgE}$ are important modulators involved in the development of the late phase of CHS. 

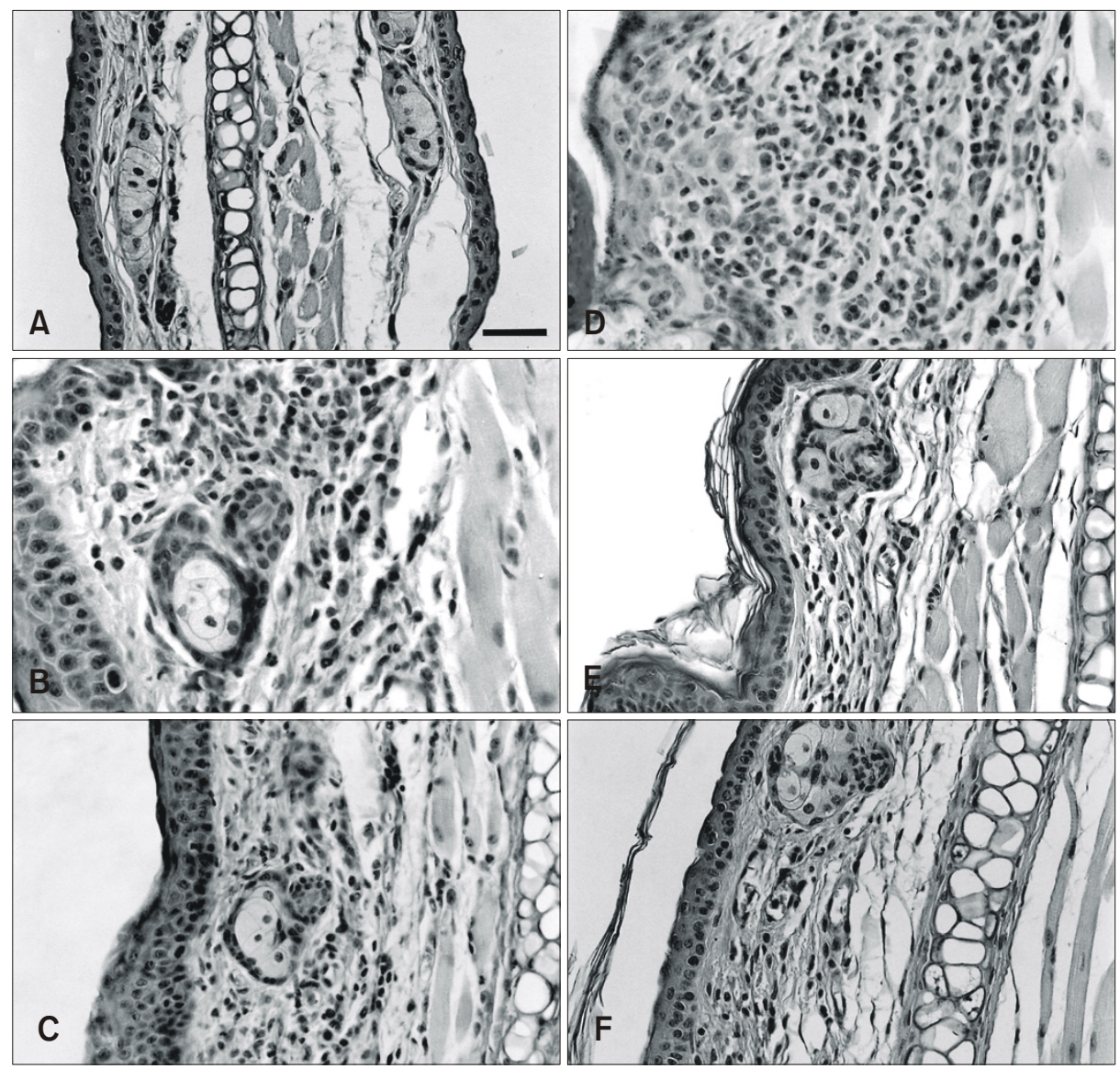

Figure 7. Light micrographs of the infiltration of eosinophils by repeated TMA challenges from the control (vehicle treated, A), TNF- $\alpha^{+/+}$ (B6129SF2/J, B) and TNF- $\alpha$ knockout TNF- $\alpha^{-1-}\left(B 6 ; 129 S-\right.$ Tnf $\left.^{\text {tm1Gk1 }}, C\right)$ mice sensitized on the back skin with TMA. The sensitized Balb/c mice were challenged with 100 $\mathrm{mg} / \mathrm{ml}$ TMA to the left ears on day 14. On day 21 , saline (D) or anti-TNF- $\alpha$ antibody ( $5 \mathrm{mg} /$ mouse, E) was injected into the peritoneal cavity at $5 \mathrm{~min}$ before the second TMA challenge. On day 14 , anti-lgE antibody $(20 \mu \mathrm{g} /$ mouse, $\mathrm{F})$ was injected subcutaneously at $24 \mathrm{~h}$ before the first TMA challenge. Congo red stain, $\mathrm{Bar}=50 \mu \mathrm{m}$.
Table 2. The number of polymorphonuclear leukocytes (PMNLs) and eosinophils (Eos) per unit area $\left(\mathrm{mm}^{2}\right)$ on $48 \mathrm{~h}$ after two repeated TMA challenges in the ears of Balb/c mice.

\begin{tabular}{lll}
\hline Groups $^{\text {a) }}$ & No. of PMNLs & No. of Eos $^{\text {c) }}$ \\
\hline Saline & $792.8 \pm 110$ & $345.6 \pm 56.13$ \\
5 mg of anti-TNF- $\alpha$ Ab & $268.6 \pm 30.1^{*}$ & $142.4 \pm 21.4^{*}$ \\
$20 \mu$ g of anti-lgE Ab & $153.1 \pm 15.9^{*}$ & $85.1 \pm 10.8^{*}$ \\
\hline
\end{tabular}

${ }^{a)}$ The sensitized mice were challenged with $100 \mathrm{mg} / \mathrm{ml}$ TMA to the left ears on day 14. On day 21, anti-TNF- $\alpha$ antibody was injected into the peritoneal cavity at $5 \mathrm{~min}$ before the second TMA challenge. Anti-lgE antibodies were injected $24 \mathrm{~h}$ before $100 \mathrm{mg} / \mathrm{ml}$ TMA challenge on day 14. In control group, saline instead of anti-TNF- $\alpha$ antibody or anti-lgE was injected into the peritoneal cavity or subcutaneously. ${ }^{\text {b) }}$ See the foot note of Table 1 -a. ${ }^{*}$ Difference from saline, $P<0.05 .{ }^{c}$ ) See the foot note of Table 1-b. *Difference from saline, $P<0.05$.

\section{Discussion}

In 1935, Landsteiner and Jacobs showed that epicutaneous application of small reactive compounds results in the induction of CHS (Landsteiner and Jacobs, 1935). The first treatment (sensitization) had no visible effect, but when the same hapten was applied a second time (elicitation) after a week, a local inflammation at the site of application occurs with a delay of 24-48 $\mathrm{h}$.

In this study, we have found that the repeated challenges of TMA induced biphasic ESR, an early and a late phase responses. The repetition of the challenge enlarged the extent of an early and a late phase of $\mathrm{CHS}$ in TNF $-\alpha^{+/+}$(B6129SF2/J) and Balb/c mice. In the late phase of TMA-induced $\mathrm{CHS}$, the peak of ESR by single challenge showed at $24 \mathrm{~h}$ after challenge, whereas the peak was observed at $8 \mathrm{~h}$ after repeated challenge. At the repeatedly TMA-challenged skin sites, the number of dermal PMNLs and eosinophils was increased. Dilatation of blood vessels in the dermis of skin was observed. Plugs of PMNLs and eosinophils in the ears were also observed in stratum corneum of the epidermis. The morphologic studies on the delayed type $\mathrm{CHS}$ in human have reported a number of important features to characterize these reactions (Dvorak et al., 1974; 1976a; 1976b). These include infiltration and 
piecemeal degranulation of basophils, degranulation and replication of fixed tissue mast cells, infiltration of eosinophils and neutrophils, increased vascular permeability leading to dermal and epidermal edema, vascular compaction, and erythrocyte extravasation; microvascular alterations affecting endothelial cells and pericytes, with compromise of vessel lumina and basement membrane thickening. Histological examination has also revealed the infiltration of basophils and eosinophils in the superficial dermis as the characteristics of the animal skin reaction (Sugawara et al., 1993).

Studies have demonstrated that the local release of cytokines, including TNF- $\alpha$, IL-1, and IFN- $\gamma$, is critical for the optimal generation of the $\mathrm{CHS}$ and that TNF- $\alpha$ is believed to play a role in the pathogenesis of asthma in humans and asthma and CHS in animal models (Piguet et al., 1991; Kondo et al., 1995; Wang et al., 2003). TNF- $\alpha$, which is recognized as a powerful mediator of inflammatory reaction, might induce these alterations either directly, since it can react with a wide range of cell types (Beutler and Cerami, 1989), or indirectly by the activation of several other cells. Our study has revealed that the extent of ESR observed in TNF- $\alpha^{-1-}$ mice was significantly lower than that in TNF- $\alpha^{+/+}$mice. Treatment of anti-TNF- $\alpha$ antibody decreases the magnitude of a late phase response of $\mathrm{CHS}$. Histologically, infiltration of PMNLs and eosinophils increased in repeatedly TMA-challenged the TNF- $\alpha^{-/-}$mice, but the extent of the infiltration is decreased as compared to that in TNF- $\alpha^{+/+}$mice. Administration of anti-TNF- $\alpha$ antibody also decreased significantly the infiltration of PMNLs and eosinophils into the dermis of TMA-challenged Balb/c mice. Our data are in agree with the report of Nakae and colleague (2003), which showed that $\mathrm{CHS}$ is suppressed by the injection of anti-TNF- $\alpha$ antibody. Oxazolone-induced CHS is reduced in TNF- $\alpha^{-1-}$ and TNF receptor $\mathrm{II}^{-1-}$ mice (Pasparakis et al., 1996; Wang et al., 1997). Piguet and colleague (1991) have reported three lines of evidence that argue in favor of a major role of TNF- $\alpha$ in both irritant reaction and CHS; first, these reactions are associated with a marked rise in the TNF- $\alpha$ mRNA level; second, they are considerably reduced or abrogated by treatment with anti-TNF- $\alpha$ antibody; third, a continuous hypodermal infusion of TNF can reproduce many of the dermal or epidermal features of CHS, notably epidermal necrosis, dermal leukocytic infiltration, and hemorrhagic necrosis (Piguet et al., 1990). Treatment of anti-TNF- $\alpha$ antibody prevents the various features of the CHS, as seen on histological sections, e.g., leukocyte infiltration and hemorrhages within the dermis and keratinocytes necrosis. It has been demonstrated that TNF- $\alpha$ mRNA is detectable in an untreated ear, increases after the application of trinitrochlorobenzene in nonsensitized mice, and is highest in sensitized mice. A study has reported that TNF- $\alpha$ mRNA accumulation, which is evident $0.5 \mathrm{~h}$ after hapten application, is abolished by the treatment with anti-TNF- $\alpha$ antibody (Piguet et al., 1991).

Although an involvement of other cytokines such as IL-1 and IL-4 in CHS development is only obvious under conditions using specific allergens or specific genetic backgrounds (Nagai et al., 2000; Nakae et al., 2003), it is clearly observed using TMA as contact allergen that TNF- $\alpha$ for CHS development is a critical factor.

IgE antibodies mediate allergic diseases by binding to specific high affinity receptors (FceRI) on mast cells and basophils. An increase in production of IgE in response to common environmental antigens is the hallmark of allergic diseases such as bronchial asthma, allergic rhinitis, and atopic dermatitis (Burr, 1993). There is an evidence for the importance of $\lg \mathrm{E}$ in the development of bronchial asthma, in that studies have demonstrated a correlation between IgE serum levels and the prevalence (Burrows et al., 1989) or severity (Sears et al., 1991). Therefore, the IgE/FceRI interaction is a target for clinical intervention in allergic diseases. Yokozeki and colleague have demonstrated that Th2 cytokines (IL-4 and $\mathrm{IL}-5)$ and $\lg \mathrm{E}$ as well as mast cells play an essential role in the induction of para-phenylenediamineinduced CHS (2003). Our results show that treatment of anti-lgE antibody decreases the magnitude of a late phase of CHS. Histologically, anti-lgE antibody also significantly reduces infiltration of PMNLs and eosinophils into the dermis of TMA-challenged Balb/c mice. Our data are in agree with revious reports, which show that IgE plays a critical role in the production of Th2 cytokienes in the development of eosinophil recruitment into the inflammation site after antigen provocation and the initial development of the late allergic responses (Haile et al., 1999; Tumas et al., 2001; Yokozeki et al., 2003; Coyle et al., 2005).

In summary, TMA can be used to establish a murine model of CHS, and TNF- $\alpha$ and $\lg E$ may act as potential modulators in the TMA-induced CHS. Neutralization of TNF- $\alpha$ and IgE by anti-TNF- $\alpha$ or anti-IgE antibodies may provide a therapeutic tool for the treatment of TMA-induced CHS.

\section{Acknowledgement}

This study was supported by grants from the Medical Science and Engineering Research Center of the Korea Science and Engineering Foundation (R13-2002038-01003-0: CH Song) and the National Research Labolatory Program (YC Lee), Republic of Korea. 


\section{References}

Askenase PW, van Loveren $\mathrm{H}$, Kraeuter-Kops $\mathrm{S}$, Ron $\mathrm{Y}$, Meade R, Theoharides TC, Nordlund JJ, Scovern H, Gerhson MD, Ptak W. Defective elicitation of delayed-type hypersensitivity in $\mathrm{W} / \mathrm{W}^{\mathrm{V}}$ and $\mathrm{SI} / \mathrm{SI}^{\mathrm{d}}$ mast cell-deficient mice. $\mathrm{J}$ Immunol 1983;131:2687-94

Beutler B, Cerami A. The biology of cachectin/TNF-A primary mediator of the host response. Annu Rev Immunol 1989;7:625-55

Bradding P, Roberts JA, Britten KM, Montefort S, Djukanovice $\mathrm{R}$, Mueller R, Heusser $\mathrm{CH}$, Howarth $\mathrm{PH}$, Holgate ST. Interleukin- $4,-5$ and -6 and tumor necrosis factor- $\alpha$ in normal and asthmatic airways: evidence for the human mast cell as source of these cytokines. Am J Respir Cell Mol Biol 1994; $10: 471-80$

Caux C, Liu YJ, Banchereau J. Recent advances in the study of dendritic cells and follicular dendritic cells. Immunol Today 1995;16:2-4

Choi IW, Kim YS, Kim DK, Choi JH, Seo KH, Im SY, Kwon $\mathrm{KS}$, Lee MS, Ha TY, Lee HK. Platelet-activating factormediated NF- $\kappa B$ dependency of a late anaphylactic reaction. J Exp Med 2003;198:145-51

Coyle AJ, Wagner K, Bertrand C, Tsuyuki S, Bews J, Heusser C. Central role of immunoglobulin (Ig) $E$ in the inducetion of lung eosinophil infiltration and $\mathrm{T}$ helper 2 cell cytokine production: Inhibition by a non-anaphylactogenic anti-IgE antibody. J Exp Med 1996;183:1303-10

Cumberbatch M, Kimber I. Tumor necrosis factor- $\alpha$ is required for accumulation of dendritic cells in draining lymph nodes and for optimal contact sensitization. Immunology 1995;84:31-5

Dvorak AM, Mihm MC, Dvorak HF. Morphology of delayedtype hypersensitivity reactions in man. II. Ultrastructural alterations affecting the microvasculature and the tissue mast cells. Lab Invest 1976a;34:179-91

Dvorak HF, Mihm MC, Dvorak AM, Johson RA, Manseau EJ, Morgan E, Colvin RB. Morphology of delayed-type hypersensitivity reactions in man. I. Quantitative description of the inflammatory response. Lab Invest 1974;31:111-30

Dvorak HF, Mihm MC, Dvorak AM. Morphology of delayedtype hypersensitivity reactions in man. J Invest Dermatol 1976b;67:391-401

Gordon JR, Galli SJ. Mast cells as a source of both preformed and immunologically inducible TNF- $\alpha /$ cachectin. Nature 1990;346:274-6

Grabbe S, Schwarz T. Immunoregulatory mechanisms involved in elicitation of allergic contact hypersensitivity. Immunol Today 1998;19:37-44

Haile S, Lefort J, Eum EY, Dumerey C, Huerre M, Heusser C, Vargaftig BB. Suppression of immediate and late responses to antigen by a non-anaphylactogenic anti-lgE antibody in a murine model of asthma. Eur Respir J 1999; 13:961-9

Hofsli E, Lamvik J, Nissen-Meyer J. Evidence that tumor necrosis factor (TNF) is not constitutively present in vivo: the association of TNF with freshly isolated monocytes reflects a rapid in vitro production. Scand J Immunol 1988;28:435-41

Kim JY, Choi SP, La SJ, Seo JS, Kim KK, Nam SH, Kwon BS. Constitutive expression of 4-1BB on T cells enhances CD4(+) T cell responses. Exp Mol Med 2003;35:509-17

Kondo S, Pastor S, Fujisawa H, Shivji GM, McKenzie RC, Dinarello CA, Sauder DN. Interleukin-1 receptor antagonist suppresses contact hypersensitivity. J Invest Dermatol 1995; 105:334-8

Landsteiner K, Jacobs E. Studies on the sensitization of animals with simple chemical compounds. J Exp Med 1935; 61:643-52

Lauerma Al, Fenn B, Maibach HI. Trimellitic anhydridesensitive mouse as an animal model for contact urticaria. $J$ Appl Toxicol 1997;17:357-60

Lee SK, Lee SS, Song IS, Kim YS, Park YW, Joo JY, Um HS, Kim JW, Kim KY, Choi SJ, Jung KH, Chung SI. Paradoxical effects of elastase inhibitor guamerin on the tissue repair of two different wound models: sealed cutaneous and exposed tongue wounds. Exp Mol Med 2004;36:259-67

Mapp C, Boschetto P, Miotto D, de Rosa E, Fabbri LM. Mechanisms of occupational asthma. Ann Allergy Asthma Immunol 1999;23:214-64

Nagai $\mathrm{H}$, Ueda $\mathrm{Y}$, Ochi $\mathrm{T}$, Hirano $\mathrm{Y}$, Tanaka $\mathrm{H}$, Inagaki $\mathrm{N}$, Kawada K. Different role of IL-4 in the onset of hapteninduced contact hypersensitivity in Balb/c and C57BL/6 mice. Br J Pharmacol 2000;129:299-306

Nakae S, Komiyama Y, Narumi S, Sudo K, Horai R, Tagawa Y, Sekikawa K, Matsushima K, Asano M, Iwakura Y. IL-1-induced tumor necrosis factor- $\alpha$ elicits inflammatory cell infiltration in the skin by inducing IFN- $\gamma$-inducible protein 10 in the elicitation phase of the contact hypersensitivity response. Int Immunol 2003;15:251-60

Ohkawara Y, Yamauchi K, Tanno Y, Tamura G, Ohtani H, Nagura $\mathrm{H}$, Ohkuda $\mathrm{K}$, Takishima $\mathrm{T}$. Human lung mast cells and pulmonary macrophages produce tumor necrosis factor$\alpha$ in sensitized lung tissue after $\lg E$ receptor triggering. Am J Respir Cell Mol Biol 1992;7:385-92

Pasparakis M, Alexopoulou L, Episkopou V, Kollis G. Immune and inflammatory responses in TNF- $\alpha$-deficient mice: a critical requirement for TNF- $\alpha$ in the formation of primary $B$ cell follicles, follicular dendritic cell networks and germinal centers, and in the maturation of the humoral immune response. J Exp Med 1996;184:1397-411

Piguet PF, Grau GE, Hauser C, Vassalli P. Tumor necrosis factor is a critical mediator in hapten-induced irritant and contact hypersensitivity reactions. J Exp Med 1991;173:673-9

Piguet PF, Grau GE, Vassalli P. Subcutaneous perfusion of tumor necrosis factor induces local proliferation of fibroblasts, capillaries, and epidermal cells, or massive tissue necrosis. Am J Pathol 1990;136:103-10

Roake JA, Rao AS, Morris PJ, Larsen CP, Hankins DF, Austyn JM. Dendeitic cell loss from nonlymphoid tissues after systemic administration of lipopolysaccharide, tumor necrosis factor, and interleukin 1. J Exp Med 1995;181:223747 
Shah A, Church MK, Holgate ST. Tumor necrosis factor alpha: a potential mediator of asthma. Clin Exp Allergy 1995;25:1038-44

Song $\mathrm{CH}$, Galli SJ, Lantz CS, Hu X, Stevens RL, Friend DS. 13 congo red staning of intraepithelial mucosal mast cells. J Histochem Cytochem 1999;47:1645C-1645

Stern RL, Manders SM, Buttress SH, Heymann WR. Urticaria pigmentosa presenting with massive peripheral eosinophilia. Pediatr Dermatol 1997;14:284-6

Stingl G, Bergstresser PR. Dendritic cells: a major story unfolds. Immunol Today 1995;16:330-3

Sugawara $Y$, Okamoto $Y$, Sawahata T, Tanaka K. Skin reactivity in guinea pigs sensitized with 2,4-toluene diisocyanate. Int Arch Allergy Immunol 1993;100:190-6

Tumas DB, Chan B, Werther W, Wrin T, Vennari J, Desjardin N, Shields RL, Jardieu P. Anti-lgE efficacy in murine asthma models is dependent on the method of allergen sensitization. J Allergy Clin Immunol 2001;107:1025-33

Van Houwelingen $\mathrm{AH}$, Kool M, de Jager SA, Redegeld FM, van Heuven-Nolsen D, Kraneveld AD, Nijkamp FP. Mast cell-derived TNF- $\alpha$ primes sensory nerve endings in a pulmonary hypersensitivity reaction. J Immunol 2002;168:5297302
Van Loveren H, Meade R, Askenase PW. An early component of delayed-type hypersensitivity mediated by $T$ cells and mast cells. J Exp Med 1983;157:1604-17

Vassalli $P$. The pathophysiology of tumor necrosis factors. Ann Rev Immunol 1992;10:411-52

Wang B, Esche C, Mamelak A, Freed I, Watanabe H, Sauder DN. Cytokine knoctouts in contact hypersensitivity research. Cytokine Growth Factor Rev 2003;14:381-9

Wang B, Fujisawa H, Zhuang L, Kondo S, Shivji GM, Kim CS, Mak TW, Sauder DN. Depressed Langerhans cell migration and reduced contact hypersensitivity response in mice lacking TNF-receptor p75. J Immunol 1997;159:614855

Yokozeki $\mathrm{H}$, Wu MH, Sumi K, Igawa K, Miyazaki $\mathrm{Y}$, Katayama I, Takeda K, Akira S, Nishioka K. Th2 cytokines, $\mathrm{IgE}$ and mast cells play a crucial role in the induction of para-phenylenediamine-induced contact hypersensitivity in mice. Clin Exp Immunol 2003;132:385-92

Zhang XD, Murray DK, Lewis DM, Siegel PD. Dose-response and time course of specific $\lg E$ and $\lg G$ after single and repeated topical skin exposure to dry trimellitic anhydride powder in a Brown Norway rat model. Allergy 2002; $57: 620-6$ 